\title{
SALINITY EFFECT ON SEEDLING GROWTH, WATER, SODIUM AND POTASSIUM DISTRIBUTIONS IN THE MANGROVE SPECIES (Avicennia germinans L. (AVICENNIACEAE)) IN SEMI CONTROLLED CONDITIONS
}

\author{
V.D.TAFFOUO ${ }^{1}$, T. FONKOU ${ }^{2}$, M. KENNE 3 , O. F. WAMBA ${ }^{1}$ and A. AKOA ${ }^{4}$ \\ ${ }^{1}$ Department of Botany, Faculty of Science, University of Douala, PO Box : 24157 Douala - Cameroon \\ E-mail : Vtaffouo@yahoo.fr ; \\ ${ }^{2}$ Department of Botany, Faculty of Science, University of Dschang, PO Box : 377 Dschang - Cameroon \\ ${ }^{3}$ Department of Biology and Animal Physiology, Faculty of Science, University of Douala, PO Box : 24157 \\ Douala - Cameroon; \\ ${ }^{4}$ Department of Botany, Faculty of Science, University of Yaoundé I, P.O. Box : 812 Yaoundé - Cameroon.
}

\begin{abstract}
The effect on plant growth of $\mathrm{NaCl}$ concentrations in soil, under semi-controlled conditions, water content and monovalent cations $\left(\mathrm{Na}^{+}\right.$and $\left.\mathrm{K}^{+}\right)$distributions in seedlings of Avicennia germinans were studied. After 4 weeks of growth, results show that $\mathrm{NaCl}$ affected leaf growth more than roots and stems. For the two lower vegetal organs, 100 mmoles of $\mathrm{NaCl}$ brought about a significant increase in plant growth. A high retention rate of $\mathrm{Na}$ was noted in seedling epicotyl axes, contributing in delaying young leaves proliferation and thereby, preventing the toxic effects of this ion. Mature leaves exhibited good adaptative behavior toward salinity stress by increasing succulence due to absorption of large quantities of water and $\mathrm{K}^{+}$in leaves. Potassium uptake in leaves was not found to be affected by $\mathrm{NaCl}$ concentration. As a consequence, monovalent cations adsorption resulted in an increase in the water contents of the plant organs. The high accumulation of $\mathrm{K}^{+}$ in leaves of $A$. germinans show that this ion was the major element responsible for osmotic adjustment in leaf cells.
\end{abstract}

Key words : Mangrove, Avicennia germinans, salinity, ionic transport, Cameroon.

\section{RESUME}

EFFET DE LA SALINITE SUR LA CROISSANCE, LA DISTRIBUTION DES TENEURS EN EAU, SODIUM ET POTASSIUM D'UNE ESPECE DE MANGROVE (AVicennia germinans L. (AVICENNIACEAE)) EN CONDITIONS SEMI-CONTROLEES

L'effet de différentes concentrations du milieu en $\mathrm{NaCl}$ sur la croissance de la plante, l'état hydrique et la distribution des cations monovalents $\left(\mathrm{Na}^{+}\right.$et $\left.\mathrm{K}^{+}\right)$au niveau des organes de Avicennia germinans a été étudié en conditions semi-contrôlées. Après 4 semaines de culture, les résultats montrent que le $\mathrm{NaCl}$ améliore significativement plus la croissance des feuilles que celle des racines et des tiges. Pour ces derniers organes, une concentration de 100 mmoles de $\mathrm{NaCl}$ a entraîné une meilleure croissance. Une forte rétention de $\mathrm{Na}$ a été observée au niveau des axes épicotylés des plantules, contribuant à réduire l'envahissement des jeunes feuilles et par conséquent, éviter les effets toxiques de cet ion. Les feuilles plus âgées s'adaptent aux conditions de salinité, à travers l'augmentation de la succulence, due à une absorption massive d'eau et de $K^{+}$. L'approvisionnement en $K^{+}$des feuilles n'a pas été affecté par la présence de $\mathrm{NaCl}$ dans le milieu. Par conséquent, l'absorption des cations monovalents $\mathrm{Na}^{+}$et $\mathrm{K}^{+}$a entrainé une augmentation de la teneur en eau des organes étudiés. La forte accumulation de $\mathrm{K}^{+}$, au niveau des feuilles, montre que chez A. germinans, cet ion est le principal élément responsable de l'ajustement osmotique des cellules foliaires.

Mots clés : Mangrove, Avicennia germinans, salinité, transport ionique, Cameroun. 


\section{INTRODUCTION}

Mangrove vegetation is generally dominated by halophytic woody plant species, among which Avicennia species are the most tolerant to both high and fluctuating water salinity, ranging from low in estuarine habitats to hypersaline conditions in sites regularly fed by seawater (Mallery and Teas, 1984 ; Ball, 1996 ; Suárez et al., 1998 ; Hajer et al., 2006). As the mangrove environmental conditions affect the survival and the productivity of the colonising plants species, plant structures and physiological features explain their ecological success under harsh conditions (Clough et al., 1982 ; Smith et al., 1989 ; Ball, 1996 ; Suárez et al., 1998 ; Munns, 2002). For example, several studies revealed that photosynthesis activity and growth of mangrove plant species are reduced as salinity of the medium was increases (Ball and Farquhar, 1984 ; Smith et al., 1989 ; Azócar et al., 1992 ; Sobrado, 1999a, 1999b ; Sobrado and Ball, 1999). Moreover, studies in Australia mangrove sites showed that the height of mangrove species and their diameter, at breast height, were related to soil-water salinity, soil-water content and distance from the mouth of the estuary. Consequently, characteristics of those mangroves are not a simple response to salinity gradients in diverse systems; other variables such as nutrient availability may be important in controlling mangrove growth (Saintilan, 1998 ; Munns, 2002).

Although some studies have demonstrated that mangroves growing in natural conditions are able to tolerate high soil salinity conditions and water potentials, plant physiological mechanism, involving several processes, are poorly known. Regulation of ion uptake and ion transport mechanisms allow plant to adapt more easily to high salinity situations of the site and then maintaining a favourable water and carbon balance (Clough et al., 1982). In mangroves, water deficits are generally tolerated, due to ion uptake and an increase of intracellular solute concentration. Consequently, the resulting decrease in osmotic potential allows mangrove cells to lower their water content below that of seawater, in order to maintain a positive water uptake at roots level (Scholander, 1964, 1968).

In Avicennia germinans (which is the common species in old mangrove vegetation, where the effect of nutrient availability is overwhelmed by the tolerance of individual species to salt stress) leaves adapt easily to hypersaline soils by increasing their solute concentration and cell elasticity (Chen Ronghua and Twilley, 1998 ; Suárez et al., 1998 ; El-lklil et al., 2002 ; Trinchant et al., 2004 ; Le Rudulier, 2005 ; Taffouo, 2005). Although A. germinans plays an important ecological role in coastal structures by trapping sediments and stabilising the delta plains (Froimard, 1998). Little is known about the salinity effects at the levels of its vegetal parts, except few studies concerning carbon assimilation by leaves (Sobrado, 1999a, 1999b ; Sobrado and Ball, 1999). In this study, we assumed that differences in cation concentrations from roots to leaves of $A$. germinans seedlings may be modified relatively to salinity conditions to maintain a favourable water balance and the positive cell tugor required for growth. Therefore, the aim of the study is to assess the cations distribution in vegetal parts of $A$. germinans seedlings to different $\mathrm{NaCl}$ concentrations under controlled conditions.

\section{MATERIALS AND METHODS}

\section{SEEDLINGS}

Studies were set up on seedlings growing under controlled conditions. Seeds originating from the mangrove of the cameroonian estuary were first disinfected using a sodium hypochlorite solution at $10 \%$ for 1 hour seeds were their rinsed using distilled water and stored for germination studies. After three days, seedlings were separated into 4 groups of 15 individuals each. For each group, 5 seedlings were randomly selected and planted together in one pot containing sand (previously cleaned and rinsed using, respectively $\mathrm{HCl}$ and distilled water) with three replicates. Pots were placed in the laboratory and supplied, every three days, with a nutrient solution (composition : 0.4 $\mathrm{mN}$ of $\mathrm{KNO}_{3}, 0,2 \mathrm{mN}$ of $\mathrm{KH}_{2} \mathrm{PO}_{4}, 1,0 \mathrm{mN}$ of $\mathrm{Ca}_{2} \mathrm{NO}_{3}$ and $0,4 \mathrm{mN}$ de $\mathrm{MgSO}_{4}$; temperature : $26 \pm 3{ }^{\circ} \mathrm{C}$; light : 5000 lux during 12 hours ; atmosphere relative humidity : 51 à $70 \%$ ) (Wacquant, 1974).

\section{TREATMENTS}

The control group of seedlings was fed using a nutritive solution $(\mathrm{pH}=6)$ without salt $(0$ mmoles of $\mathrm{NaCl}$ ), while the three experimental groups were supplied daily with different salt concentrated nutritive solution $(50,100$ and 
200 mmoles of $\mathrm{NaCl}$, respectively). After one week of culture, two growth parameters were recorded in each group of seedlings : (1) the vegetal height was measured every two days, and (2) the dry weight was obtained every one week on randomly sampled plants. Four weeks later, the water and cations $\left(\mathrm{Na}^{+}\right.$and $\left.\mathrm{K}^{+}\right)$contents of vegetal organs (leaves, stems and roots) were determined on 15 randomly sampled plants for each group of seedlings (Savouré, 1980 ; Tsoata and Taffouo, 1997).

\section{STATISTICALANALYSIS}

Data are presented in term of mean ( \pm standard deviation). Correlation coefficients between studied parameters as well as coefficient of determination (square of correlation coefficients) and regression equations are given. Correlation coefficients and linear regression slopes $( \pm$ standard deviation) are compared using the Student t-test. Multiple comparison of several means was set up using the ANOVA method following by all pairwise analysis using the Student-Newman-Keuls procedure when the normality and equal variance conditions passed. When conditions were not matched the KruskallWallis non-parametric multiple test was used and analytic comparisons set up using the Dunn's method. Multiple comparisons of data noted in experimental groups versus those recorded in the single control group were set up using the Dunnett's procedure (SigmaStat sofware).

\section{RESULTS}

\section{SEEDLING GROWTH}

Growth parameters recorded on seedlings showed that whatever the salinity of the medium, their height varied positively according to the duration of culture. The growth inhibition effect of the salt was significantly noted for 200 mmoles of $\mathrm{NaCl}$ on height (Table 1). Moreover, the dry matter was higher in stems and roots than in leaves (Figure 1). Comparisons between the control and experimental group of plants permitted us to note that the presence of salt in the nutritive solution did not affect the dry matter of roots and stems except the case of 100 mmoles of $\mathrm{NaCl}$ after three weeks (Figure 1).

\section{IONICDISTRIBUTION}

Potassium ions were more concentrated in leaves (551-1000 $\mathrm{mEq} / \mathrm{g} \mathrm{DM})$ than in the three other vegetal organs (91-320 $\mathrm{mEq} / \mathrm{g}$ DM). Between the three later organs, ion concentration was higher in roots than in the two parts of stems (Figure 2A). Pairwise comparisons between the control and the three experimental groups of plants showed that differences in ionic distribution, recorded in leaves and roots, were, in all cases, significant (Dunnett's test : $\mathrm{P}<0.001$ for leaves and roots, respectively). Whereas, in épicotyl and hypocotyl axes, a significant difference was noted only between the control plants and those fed using 200 mmoles of $\mathrm{NaCl}$ (Figure 2A).

Contrary to $\mathrm{K}^{+}, \mathrm{Na}^{+}$ions accumulated more in studied organs of experimental groups of plants (600-1610 mEq/g of dry matter) than in those of the control one (20-55 mEq/g of dry matter). For each experimental group of plants, sodium was more concentrated in epicotyl axis than other vegetal organs (Figure 2B). Moreover, as overall studies, whatever the group of plants, the ionic ratio was more important in epicotyl and hypocotyl axis than in leaves and roots (Figure 2C).

Comparisons of water content values in experimental groups of plants to those of the control show that the supply of $\mathrm{NaCl}$ in the medium resulted in a significant increase in roots and leaves water content contrary to stems (Table 2). 
Table 1 : Salinity effect on seedlings height and Pearson correlation coefficients between plant height variation and the duration of culture.

Effet de la salinité sur la taille des plantules et corrélation entre la variation de taille des plantules et la durée de culture.

\begin{tabular}{lccccc}
\hline \multirow{2}{*}{$\begin{array}{l}\text { Salinity } \\
(\mathrm{mmoles} \text { of NaCl})\end{array}$} & \multicolumn{3}{c}{ Height of plants $(\mathrm{cm})$} & \multicolumn{2}{c}{ Pearson correlation } \\
\cline { 2 - 6 } & Min. & Max. & Mean \pm SD & $\mathrm{r}$ & p-value \\
\hline A : 0 $(\mathrm{n}=60)$ & 4.5 & 10.2 & $7.8 \pm 1.4$ & 0.752 & $4.5 \times 10^{-12}$ \\
B : $50(\mathrm{n}=60)$ & 4.5 & 8.5 & $7.9 \pm 1.1$ & 0.615 & $1.8 \times 10^{-7}$ \\
C : $100(\mathrm{n}=60)$ & 4.5 & 10.5 & $8.4 \pm 1.6$ & 0.793 & $1.5 \times 10^{-13}$ \\
D. $200(\mathrm{n}=60)$ & 4.3 & 7.5 & $5.9 \pm 0.9$ & 0.454 & $2.5 \times 10^{-4}$ \\
\hline
\end{tabular}

Multiple comparison : normality test failed $(\mathrm{P}<0.001)$; Kruskal-Wallis One Way ANOVA : $\mathrm{H}=88.64 ; \mathrm{df}=3 ; \mathrm{P}<0.001$. Pairwise multiple comparison procedures using Dunn's method ( $d=$ difference of ranks ; $Q=$ Dunn's index)

$H=$ test non paramétrique de Kruskal-Wallis (les conditions de normalité et d'égalité des variances ne sont pas vérifiées) et les comparaisons au lot témoin sont effectuées suivant la procédure de Dunn $(d=$ différence des rangs; $Q=$ index de Dunn) ; $H=88,64 ; d f=3 ; P<0.001$
A vs. $B: d=4.28$;

$$
\begin{aligned}
& \mathrm{Q}=0.34 ; \mathrm{ns} \\
& \mathrm{Q}=1.85 ; \mathrm{ns}
\end{aligned}
$$$$
\text { B vs. } C: d=19.12 \text {; }
$$$$
\mathrm{Q}=1.51 ; \mathrm{ns}
$$
A vs. $C: d=23.40$;
$B$ vs. $D: d=90.10$;
$\mathrm{Q}=7.11$; *
A vs. $D: d=85.82$;
$\mathrm{Q}=6.77$; *
C vs. $D: d=109.22 ; \quad Q=8.62$; *
${ }^{*}=\mathrm{P}<0.05 ; \mathrm{ns}=$ not significant difference
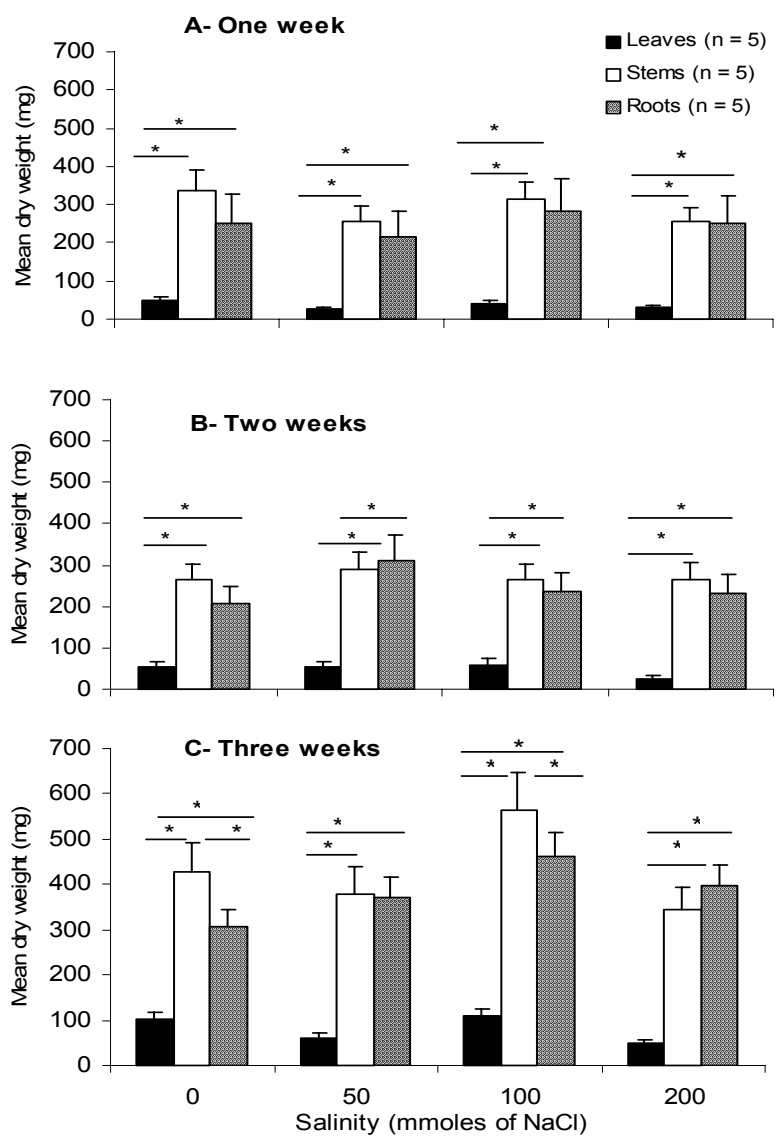

Figure 1 : Effect of salinity (mmole of $\mathrm{NaCl}$ ) and age on the dry weight $(\mathrm{mg})$ of different seedlings organs.

Effet de la salinité (mmole de $\mathrm{NaCl}$ ) et de l'âge sur le poids de la matière sèche $(\mathrm{mg})$ des organes des plantules.

Vertical bars represent standard deviation and horizontal bars a significant difference between organs. Statistical analysis were set up using the one way ANOVA method followed by the Student-Newman-Keuls pairwise multiple comparisons. ${ }^{*}=$ significant difference.

Les barres verticales représentent les déviations standard et les barres horizontales les différences significatives entre les organes. Les comparaisons statistiques multiples sont faites à l'aide de la procédure d'ANOVA et les comparaisons à postériori sont réalisées par la méthode analytique de Student-Newman-Keuls. * = différence significative. 

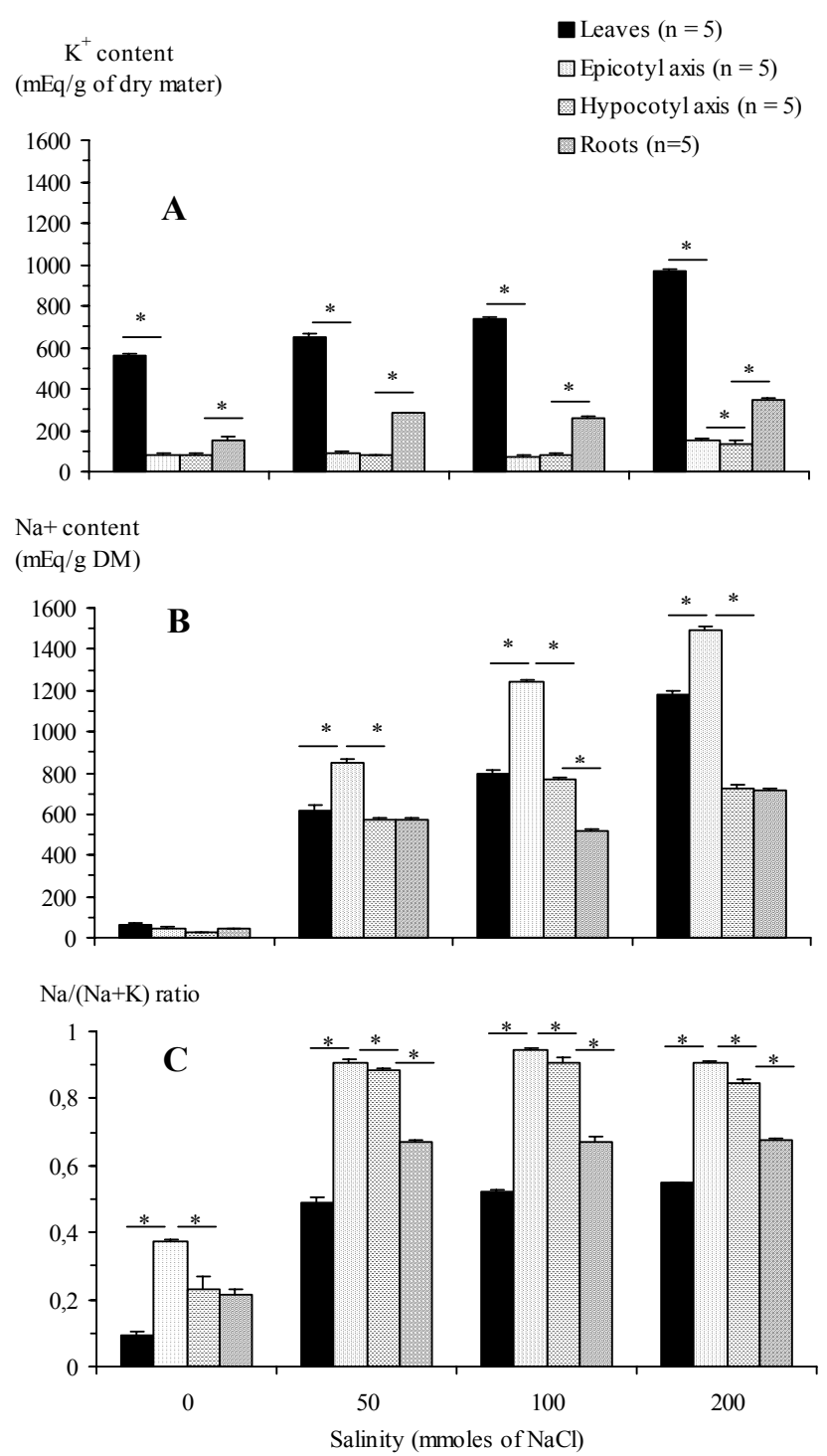

Figure 2 : Effect of salinity on the distribution of $\mathrm{K}^{+}$and $\mathrm{Na}^{+}$in seedling's organs.

Effet de la salinité sur la distribution des ions $\mathrm{K}^{+}$et $\mathrm{Na}^{+}$dans les organes des plantules.

Vertical bars : standard deviation; horizontal bars : significant difference between organs. Statistical analysis were set up using the one way ANOVA method and the Student-Newman-Keuls pairwise multiple comparisons. ${ }^{*}=$ significant difference.

Barres verticales : déviations standard ; barres horizontales : différences significatives entre organes. Analyses statistiques : ANOVA ; comparaisons à postériori : Student-Newman-Keuls. ${ }^{*}=$ différence significative.

Table 2 : Salinity effect on the water content of seedling's organs.

Effet de la salinité sur la teneur en eau des organes des plantules.

\begin{tabular}{|c|c|c|c|c|c|c|c|c|c|}
\hline \multirow{2}{*}{$\begin{array}{l}\text { Salinity } \\
\text { (mmoles of } \\
\mathrm{NaCl} \text { ) }\end{array}$} & \multicolumn{3}{|c|}{ 1. Roots } & \multicolumn{3}{|c|}{ 2. Stems } & \multicolumn{3}{|c|}{ 3. Leaves } \\
\hline & Min. & Max. & $\operatorname{Mean} \pm \mathrm{SD}$ & Min. & Max & Mean \pm SD & Min. & Max. & Mean \pm SD \\
\hline$A: 0(n=5)$ & 76.8 & 78.1 & $77.4 \pm 0.6$ & 77.6 & 79.2 & $78.5 \pm 0.7$ & 66.1 & 68.2 & $67.3 \pm 0.8$ \\
\hline B : $50(n=5)$ & 84.8 & 86.2 & $85.4 \pm 0.5 *$ & 76.8 & 78.2 & $77.5 \pm 0.6$ & 63.6 & 65.8 & $64.7 \pm 0.8 *$ \\
\hline$C: 100(n=5)$ & 86.9 & 88.5 & $87.5 \pm 0.7 *$ & 81.8 & 83.1 & $82.4 \pm 0.6$ & 78.1 & 80.0 & $79.1 \pm 0.9 *$ \\
\hline$D: 200(n=5)$ & 85.2 & 86.8 & $85.6 \pm 0.7 *$ & 79.5 & 81.0 & $80.2 \pm 0.8$ & 73.8 & 75.0 & $74.2 \pm 0.5 *$ \\
\hline
\end{tabular}

Multiple comparisons versus the control group $(0$ mmoles of $\mathrm{NaCl})$ using Dunnett's method ; ${ }^{*}=\mathrm{P}<0.05$.

Les comparaisons entre les groupes expérimentaux et le groupe témoin (cultures en milieu dépourvu de NaCl) sont réalisées à l'aide du test de Dunnett ; ${ }^{*}=P<0,05$. 


\section{DISCUSSION}

\section{GROWTHRATE}

Growth inhibition due to the presence of high concentration of $\mathrm{NaCl}$ is normaly described in glycophytes and several halophytes (Hamza, 1977 ; Sobrado, 1999a, 1999b ; Sobrado and Ball, 1999 ; Taffouo et al., 2004 ; Taffouo et al., 2006). The same phenomenon was observed in A. germinans which growth was reduced by 200 mmoles of $\mathrm{NaCl}$ (Table 1). In A. germinans the negative effet of salt on the dry matter produced was important at leaf edge. After three weeks of treatment, the growths of stems and roots was stimulated by 100 mmoles of $\mathrm{NaCl}$ (Figure 1). Our results obtained under controlled conditions were similar to those obtained previously on seedlings of Helianthus annuus and Lycopersicon esculentum (Gharsalli and Cherif, 1979 ; Agong et al., 2003 ; Hajer et al., 2006).

\section{DISTRIBUTION OF SODIUM AND POTASSIUM IONS}

In our experimental conditions, whatever the $\mathrm{NaCl}$ concentrations in the medium, the amount of accumulated $\mathrm{K}^{+}$was higher in leaves than in stems and roots (Figure 2A). The presence of $\mathrm{Na}^{+}$in the medium even in high concentration did not affect the $\mathrm{K}^{+}$uptake from mature leaves «power supply» to the youngest one «the well». This phenomenon was not restricted to mangrove plant species as, it was also reported in Phaseolus vulgaris, Gossypium hirsutum and Canavalia obtusifolia (Hamza, 1977 ; Brun, 1988 ; Taffouo et al., 2004 ; Taffouo et al., 2006). The growth inhibition observed in leaves of $A$. germinans seedlings did not appear to be correlated to $\mathrm{K}^{+}$up deficiency in leaf tissu known to be responsible of decrease in plant growth decrease in Nerium oleander (Hajji, 1979). The high accumulation of $\mathrm{K}^{+}$observed in leaves corroborates conclusions of Grillot (1957) for which potassium corresponds to about 25 to $50 \%$ of plants mineral constitution, especially in young organs, suggesting that $\mathrm{K}^{+}$may intervene during cell division.

Contrary to $\mathrm{K}^{+}, \mathrm{Na}^{+}$content was higher in epicotyl axes than in leaves, hypocotyl axes and roots. In seedlings, the storage of $\mathrm{Na}^{+}$may allow the avoidance of young leaves invasion by sodium and consequently limiting toxic effects (Strogonov, 1964 ; Munns, 2002). The same phenomenon was observed in leaves, stalks, roots and hypocotyl axes of several glycophytes and halophytes (Jacoby, 1964 ; Levitt, 1980 ; Brun, 1987 ; Slama, 1987 ; Taffouo et al., 2004).

Several field studies conducted on $A$. germinans have show that the relationship between water potential and relative water content and leaf osmotic potential of seedlings is low at low salinity sites. Moreover, in high salinity sites, anions and cations concentrations are high with low water content/unit dry mass. Consequently, leaves adapt easily to hypersaline soils by increasing their solute concentration and cell elasticity (Tattini et al., 1995 ; Rajesh et al., 1998 ; Sobrado and Ball, 1999 ; Trinchant et al., 2004 ; Le Rudulier, 2005 ; Taffouo, 2005). In our study, whatever the vegetal organ of $A$. germinans seedlings cultivated on soil supplied with $\mathrm{NaCl}$ maintained high rates of water content when compared to seedling of the control group (Table 2). Potassium accumulated more than $\mathrm{Na}^{+}$in leaves suggesting that $\mathrm{K}^{+}$is the principal element responsible for osmotic adjustment in this species. The same phenomenon was found in the natural halophytic plant Canavalia obtusifolia (Brun, 1988 ; Mezni et al., 2002). The flow of water from roots to leaves may be facilitated by the increase in ionic ratio $\mathrm{Na} /$ ( $\mathrm{Na}+\mathrm{K})$ (Figure 2C). In some halophytes, especially those of the mangrove, the principal mechanism of salt tolerance is due to the presence of specific glands at the level of leaves surface responsible of the active excretion of salts (Albert, 1975). The present study show that mature leaves were succulent due to the water retention facilitated by $\mathrm{Na}^{+}$ and $\mathrm{K}^{+}$transport. The consequence is the high intracellular dilution which helps to avoid plant poisoning. Our results corroborate findings on Medicago sativa and Hedysarum carnosum (Lessani, 1969 ; Hamza, 1977).

\section{CONCLUSION}

Overall, the supply of $\mathrm{NaCl}$ in the medium resulted in the reduction of leaf growth, whereas the growth of stems and roots was only stimulated. A. germinans appears as a facultative halophyte whose seedlings adapt easily to high salinity conditions. Young seedlings were able to accumulate important rates of $\mathrm{Na}^{+}$in epicotyl axis, increasing the 
succulence of mature leaves due to the absorption of important amount of water. Osmotic adjustment in $A$. germinans leaves, was found to be primarily due to $\mathrm{K}^{+}$accumulation.

\section{ACKNOWLEDGEMENT}

We are grateful to Dr. Mvondo Ze (University of Dschang, Cameroon) for his help during the chemical analysis of our samples.

\section{REFERENCES}

Agong S. G., M. Kingetsu, Y. Yoshida, S. Yazawa and M. Masuda. 2003. Response of tomato genotypes to induced salt stress. African Crop Science Journal 11: 133 - 142.

Albert R. 1975. Salt regulation in halophytes. Oecologia 21 (1) : 57 - 71.

Azócar A., F. Rada and A. Orozco. 1992. Water relations and gas exchange in two mangrove species with contrasting mechanisms of salt vegetation. Ecotrópicos $5: 11-19$.

Ball M. C. 1996. Comparative ecophysiology of mangrove forest and Tropical lowland moist rainforest. In : S. S. Mulkey, R. L. Chazdon and A. P. Smith (Eds.). Tropical forest plant ecophysiology. Chapman and Hall, New York : pp 461 - 496.

Ball M. C. and C. D. Farquhar. 1984. Photosynthetic and stomatal responses of the grey mangrove, Avicennia marina, to transient salinity conditions. Plant Physiol. $74: 7$ - 11.

Brun A. 1987. Effets de $\mathrm{NaCl}$ sur les teneurs en $\mathrm{Na}$ et $\mathrm{K}$ des feuilles de Canavalia obtusifolia DC : comparaison du tissu du limbe et du pétiole. C.R. Acad. Sc. Paris, t. 304 ; série III, $8: 181$ - 184 .

Brun A. 1988. Effets de $\mathrm{NaCl}$ sur une halophyte tropicale (Canavalia obtusifolia DC) : croissance, distribution de $\mathrm{Na}^{+}$et $\mathrm{K}^{+}$, état hydrique. Oecol. Plant. 9 (2) : 173 - 186.

Chen R. and R. R. Twilley. 1998. A gap dynamic model of mangrove forest development along gradients of soil salinity and nutrient resources. Aust. J. Ecol. 86 (1) : 37 - 51.

Clough B. F., T. J. Andrew and I. R. Cowan. 1982. Physiological processes in mangroves. In : B. F. Clough (Eds.). Mangrove ecosystem in Australia. Structure, Function and Management. Australia National Press, Camberra : pp 193 - 210.
El-Iklil Y., K. Mohammed, M. Rachid and B. Mohammed. 2002. Effet du stress salin sur la variation de certains metabolites chez Lycopersicom esculenta et Lycopersicom sheesmanii. Canadian Journal Plant Science $82: 177-183$.

Froimard F. 1998. L'écosystème mangrove. Biodiversité, fonctionnement, restauration et gestation. Bois et Forêt des Tropiques $256: 80-86$.

Gharsalli M. et A. Chérif. 1979. Action du chlorure de sodium sur la croissance et la teneur en lipide des plants de tournesol (Helianthus annuus L.). Physiol. Veg. 17 (2) : 215 - 229.

Grillot G. 1957. Les problèmes biologiques relatifs aux plantes tolérant l'eau salée ou saumâtre et à l'utilisation d'une telle eau pour l'irrigation. Unesco, Recherche sur la zone aride, tome IV : Utilisation des eaux salines, Paris, $152 \mathrm{p}$.

Hajer A. S., A. A. Malibari, H. S. Al-Zahrani and O. A. Almaghrabi. 2006. Responses of three tomato cultivars to see water salinity 1 . Effect of salinity on the seedling growth. Afri. J. Biotechnol. 5 (10) : 855 - 861.

Hajji M. 1979. Effets du sel sur la croissance et l'alimentation minérale du laurier-rose. Physiol. Veg. 17 (3) : 517 - 524.

Hamza M. 1977. Action de différents régimes d'apport du chlorure de sodium sur la physiologie de deux Légumineuses: Phaseolus vulgaris (sensible) et Hedysarum carnosum (tolérante). Relations hydriques et relations ioniques. Thèse de Doctorat, Université Paris VII (France), 252 p.

Jacoby B. 1964. Fonctions of bean roots and stems in sodium retention. Plant Physiol. 39 : $445-449$.

Lessani H. 1969. Recherches sur le comportement physiologique de la luzerne en présence de chlorure de sodium. Etude de quelques aspects de la nutrition minérale et du métabolisme respiratoire. Thèse Doctorat d'Etat ès Sciences, Paris (France), 152 p.

Le Rudulier D. 2005. Osmoregulation in rhizobia : The key role of compatible solutes. Grain Legume $42: 18-19$.

Levitt J. 1980. Responses of plants to environmental stresses. Vol. 2 : Water radiation, salt and other stresses. United Kingdom edition, Academic Press, London, pp 395 - 434.

Mallery C. H. and H. J. Teas. 1984. The mineral ion relations of mangroves. 1. Root cell compartments in a salt excluder and a salt 
excreter species at low salinities. Plant Cell Physiology $25: 1123$ - 1131.

Mezni M., A. Albouchi, E. Bizid and M. Hamza. 2002. Effet de la salinité des eaux d'irrigation sur la nutrition minérale chez trois variétés de luzerne pérenne (Medicago sativa). Agronomie 22: 283 - 291.

Munns R. 2002. Comparative physiology of salt and Water stress. Plant, cell and Environment, $25: 239$ - 250.

Rajesh A., R. Arumugam and V. Venkatesalu. 1998. Growth and photosynthetic characteristics of Ceriops roxburghiana under $\mathrm{NaCl}$ stress. Photosynthetica, 35 (2) : $285-287$.

Saintilan N. 1998. Relationships between height and girth of mangroves and soil-water conditions in the Mary and Hawkesbury River estuaries, eastern Australia. Aust. J. Ecol. $23(4)$ : 322 - 328.

Slama F. 1987. Recherches sur les causes de l'exclusion du sodium des feuilles des plantes sensibles à $\mathrm{NaCl}$. Agron. Trop. 7 (7) : 517 - 522.

Savouré J. C. 1980. Manipulations pratiques en physiologie végétale. Paris : Masson, $258 \mathrm{p}$.

Scholander P. F. 1964. Hydrostatic pressure and osmotic potential in leaves of mangroves and some other plants. Proc. Nat. Acad. Sci. 52 : 119 - 125.

Scholander P. F. 1968. How mangroves desalinate seawater. Plant Physiol. 21 : 251 - 261.

Smith J. A. C., M. Poop, U. Lütge, W. J. Cram, M. Diaz, H. Griffith, H. S. J. Lee, E. Medina, C. Schaefer, K. H. Stimmel and B. Thonke. 1989. Ecophysiology of xerophytic and allophytic vegetation of a costal alluvial plain in northern Venezuela. VI. Water relations and gas exchange of mangroves. New Phythol, $11: 293$ - 307.

Sobrado M. A. 1999a. Drought effects on photosynthesis of the mangrove, Avicennia germinans, under contrasting salinities. Trees, $13: 125-130$.

Sobrado M. A. 1999b. Leaf photosynthesis of the mangrove Avicennia germinans as affected by $\mathrm{NaCl}$. Photosynthetica, 36 (4) : $547-555$

Sobrado M. A. and M. C. Ball. 1999. Light use in relation to carbon gain in the mangrove,
Avicennia marina, under hypersaline conditions. Aust. J. Plant Physiol. 26 : $245-251$.

Strogonov B. P. 1964. Physiological basis of salt tolerance of plants. Oldbourne Press. London, $279 \mathrm{p}$.

Suárez N., M. A. Sobrado and E. Medina. 1998. Salinity effects on the leaf water relations components and ion accumulation patterns in Avicennia germinans (L.) seedlings. Oecologia, 114 (3) : 299 - 309.

Taffouo V. D., M. Kenne, R. Fokam Tasse, W. O. Fotsop, T. Fonkou, Z. Vondo et A. AKOA. 2004. Variation de la réponse au stress salin chez cinq espèces de Légumineuses. Agron. Afr. $16: 33$ - 44.

Taffouo V. D. 2005. Variation de la réponse au stress salin chez cinq espèces de Légumineuses : étude des marqueurs physiologiques et biochimiques. Thèse de doctorat ès Sciences, Ecophysiologie végétale, Université de Yaoundé I (Cameroun), $151 \mathrm{p}$.

Taffouo V. D., M. Kenne, O. W. Fotsop, M. L. Sameza, M. Ndomou et A. Akoa. 2006. Effets de la salinité sur la croissance, la distribution ionique et l'état hydrique d'une glycophyte tolérante : Gossypium hirsutum (Malvaceae). Journal of the Cameroon Academy of Sciences, 6 (3) : 167 - 174

Tattini M., R. Gucci, M. A. Coradeshi, C. Pangio and J. D. Everard. 1995. Growth gaz exchange and ion content in Olea europaea plants during salinity stress and subsequent relief. Physiol. Plantar. 95 (2) : 203 - 210.

Trinchant J. C., A. Boscari, G. Spennato, G. Van de Sype and D. Le Rudulier. 2004. Proline betaine accumulation and metabolism in alfalfa Plants under sodium chloride stress. Exploring its compartmentalization in nodules. Plant Physiology, $135: 1583-1594$.

Tsoata E. and V. D. Taffouo. 1997. Absorption du sodium par les parties aériennes de quatre espèces de Légumineuses. Agron. Afr. 9 (1) : 37 - 43.

Wacquant J.P. 1974. Recherche sur les propriétés d'absorption cationique des racines. Rôle physiologique et importance écologique. Thèse de doctorat, Université de Montpellier (France), $155 \mathrm{p}$. 